\title{
MEAT PRODUCTION OF DOMESTIC BALKAN GOAT KIDS
}

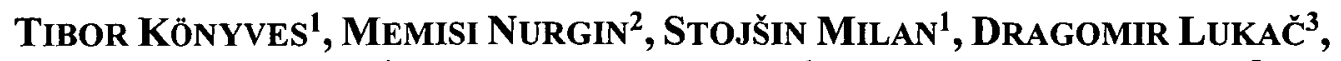 \\ PuvaČa Nikola ${ }^{4}$, Miščević BRanislavi ${ }^{1}$, MLadenović Vladica ${ }^{5}$ \\ ${ }^{1}$ Megatrend University Belgrade, Faculty of Biofarming \\ 24300 BackaTopola, Marsala Tita 39. Serbia \\ ${ }^{2}$ Dairy Plant Subotica, Tolminska 10, 24000 Subotica \\ ${ }^{3}$ University of Novi Sad, Faculty of Agriculture, Trg Dositeja Obradovića 8, 21000 Novi \\ Sad, Serbia \\ ${ }^{4}$ Patent Co., doo, Vlade Ćetkovića 1a, 24211 Mišićevo, Serbia \\ ${ }^{5}$ Vethem Ltd. Veterinary Station, 11320 Velika Plana, Miloša Velikog 132, Serbia \\ wiwat36@hotmail.com
}

\begin{abstract}
The paper presents the investigation of slaughter results, i.e. meat production and correlation between slaughter traits of kids of Balkan goat breed. Results of the study of slaughter properties are presented in this paper, also correlation between certain measures on carcass established in 96 kids of Domestic Balkan breed (gender ratio 50:50), slaughtered at the age of 90 days. Average dressing percentage of warm carcass with head and offal of investigated kid population was $58.19 \%$, whereas the value of the dressing percentage of cold carcass with head and offal was $45.19 \%$.

Male kids had statistically significantly $(\mathrm{P}<0.05$ and $\mathrm{P}<0.01)$ higher values of carcass mass compared to female kids. Data on established correlation coefficients between slaughter traits of Domestic Balkan kids reflect presence of highly positive and statistically significant $(\mathrm{P}<0.001)$ correlative dependence. Linear regression coefficients of pre-slaughter body mass of kids $(0.41$ to 0.99$)$ indicate that this trait has very significant effect on all dressing percentages and carcass.

Considering the expression of slaughter traits in kids of Balkan breed, obtained results should be used for formulating of future programs designed to improve the production of meat from autochthonous goat breeds.
\end{abstract}

Keywords: kids, domestic Balkan breed, sex of kids, slaughter results

\section{INTRODUCTION}

No statistical records were kept concerning the number of Serbian goats and their breeding because the goat keeping in Serbia was banned for a long period of time. The number of kids and goats that are yearly slaughtered here is not negligible. However, they are not available on the market, since most kids and even grown up goats are slaughtered and consumed on the firms where they were raised. That is why Serbian market is poorly supplied with this type of meat. Over the last few years the interest for breeding these very useful domestic animals changed considerably in Serbia. The number of those who are trying to establish the goat production or to enlarge their herds is increasing. In some regions this trend is especially extensive. This indicates that an increased supply of the goat meat of all categories can be soon expected on our market. Apart from the legal standards defining the quality of the goat meat of all categories as well as the quality of the animals slaughtered, it would be necessary to prescribe some other details relative to the preparation of these animals for the market. Goat population in hilly-mountainous region of Serbia is mainly domestic Balkan goat of red to sorrel colour with black, white and spotted varieties (MEMIŠI AND BAUMAN, 2007). This is a dairy breed, for which it is characteristic that the front part of the carcass is less developed than the rear part, they are of rough constitution, resistant to diseases and with very modest requirements in regard to nutrition and care. 
Since our literature lacks the reference on the fattening traits and the slaughter characteristics of the certain goat genotypes that are raised in Serbia (MEMIŠI, 2000), we wished to point to the fattening traits and some slaughter characteristics found in the kids of the domestic Balkan goat. An additional reason is that, up to now, the Balkan goat has participated, in a high percentage (about 40\%), in the breeds composing the total goat population in our country (MEMIŠI AND BAUMAN, 2007; MEMIŠI ET AL., 1998).

\section{MATERIAL AND METHOD}

The research was carried out on the herds of the Balkan goat on the farms of individual breeders, over a three years' period. Four herds of the Balkan goat were used as a material, and their productive and reproductive traits were observed during two years. In the third year, the fattening ability was tested, i.e. the production of meat in the 96 kids (24 kids in each herd, the sex ratio was 50:50), that were slaughtered at the age of 90 days. Subsequent to slaughtering and primary carcass treatment, weight of warm carcass with head and offal was registered. After cooling period of $24 \mathrm{~h}$ at the temperature of $0{ }^{\circ} \mathrm{C}$ to $4{ }^{\circ} \mathrm{C}$, weight of cold carcass with head and offal was determined, as well as without head and offal.

Statistical analysis of data was done by application of several program procedures (Proc MEANS, Proc CORR, Proc REG) of the statistical program package SAS (SAS 9.1.3, 2007).

\section{RESULTS}

Table 1 gives the mean values for the weight of the warm and cold carcass with and without the head and offal, as well as the total yield of the meat of the kids slaughtered, separated by sex.

Table 1. Mean values and carcass yield values of Balkan breed kids

\begin{tabular}{|l|c|c|c|c|c|c|}
\hline \multirow{2}{*}{ Traits } & \multirow{2}{*}{$\begin{array}{c}\text { Mean } \\
\mathrm{x} \pm \mathrm{SD} \\
(\mathrm{n}=96)\end{array}$} & \multirow{2}{*}{$\mathrm{CV}, \%$} & \multicolumn{4}{|c|}{ Male } \\
\cline { 4 - 7 } & & $\begin{array}{c}\mathrm{x} \pm \mathrm{SD} \\
(\mathrm{n}=48)\end{array}$ & $\mathrm{CV}, \%$ & $\begin{array}{c}\mathrm{x} \pm \mathrm{SD} \\
(\mathrm{n}=48)\end{array}$ & $\mathrm{CV}, \%$ \\
\hline BWBS, $\mathrm{kg}$ & $13.31 \pm 1.05$ & 7.88 & $13.50 \pm 1.11^{*}$ & 8.22 & $13.12 \pm 0.97$ & 7.39 \\
\hline WCWHP, $\mathrm{kg}$ & $7.74 \pm 0.51$ & 6.58 & $7.86 \pm 0.55^{*}$ & 6.99 & $7.62 \pm 0.45$ & 5.90 \\
\hline DPWCHP, \% & $58.19 \pm 1.33$ & 2.28 & $58.26 \pm 1.33$ & 2.28 & $58.13 \pm 1.34$ & 2.30 \\
\hline WCHCH, $\mathrm{kg}$ & $7.41 \pm 0.50$ & 6.74 & $7.53 \pm 0.53^{*}$ & 7.03 & $7.29 \pm 0.44$ & 6.03 \\
\hline DPCCHP, \% & $55.75 \pm 1.23$ & 2.20 & $55.83 \pm 1.24$ & 2.22 & $55.66 \pm 1.23$ & 2.20 \\
\hline WCHCHP, $\mathrm{kg}$ & $6.01 \pm 0.37$ & 6.15 & $6.10 \pm 0.39^{*}$ & 6.39 & $5.92 \pm 0.32$ & 5.40 \\
\hline DPCT, \% & $45.19 \pm 1.31$ & 2.89 & $45.23 \pm 1.36$ & 3.00 & $45.15 \pm 1.27$ & 2.81 \\
\hline
\end{tabular}

BWBS- Body weight before slaughter; WCWHP- Warm carcass weight with head and offal; DPWCHP- Dressing percentage at warm carcass with head and offal; WCHCH- Weight at chilled with head and offal; DPCCHP- Dressing percentage at chilled carcass with head and offal; WCHCHP- Weight at chilled carcass without head and offal; DPCTDressing percentage of cold carcass; ${ }^{*} \mathrm{P}<0.05$.

Coefficients of determination (Table 2) indicate that the percentage of variability of studied dressing percentage values was in range from 0.41 to 0.99 , which confirms the effect of pre-slaughter body weight of kids on observed slaughter characteristics. 
Review on Agriculture and Rural Development 2016 vol. 5 (1-2) ISSN 2063-4803

Table 2. Coefficients and significance of linear regression of pre-slaughter body weight on major slaughter traits of Balkan breed kids

\begin{tabular}{|l|c|c|c|c|}
\hline Traits & $\mathrm{R}^{2}$ & $\mathrm{~F}(1.94)$ & $\mathrm{r}$ & $p$ \\
\hline Weight of warm carcass with head and offal, $\mathrm{kg}$ & 0.99 & 1357.7 & 0.469906 & 0.00 \\
\hline DP of warm carcass with head and offal, \% & 0.44 & 76.768 & -0.83383 & 0.00 \\
\hline Weight of cold carcass with head and offal, kg & 0.94 & 1406.1 & 0.458049 & 0.00 \\
\hline DP of cold carcass with head and offal, \% & 0.41 & 64.910 & -0.74658 & 0.00 \\
\hline Weight of cold carcass without offal, kg & 0.89 & 785.81 & 0.327852 & 0.00 \\
\hline DP of cold carcass without offal, \% & 0.51 & 97.332 & -0.88297 & 0.00 \\
\hline
\end{tabular}

$D P$ - Dressing percentage

\section{DISCUSSION}

Data obtained on slaughter traits of Domestic Balkan goat can be compared to results obtained by other authors, but there are certain discrepancies considering the diversity in breeds, body masses and ages of kids included in trials.

The most significant results show that pre-slaughter body mass of Balkan breed kids at the age of 90 days in average was $13.3 \mathrm{~kg}$, average dressing percentage of warm carcass with head and offal approximately $58.2 \%$, whereas the average dressing percentage of cold carcass without head and offal was approximately $45.2 \%$.

Higher values of dressing percentage were established in male kids compared to female kids. However, statistically significant differences $(p<0.05)$ were determined in mass of cold and warm carcass with head and offal, as well as mass of cold carcass without offal. Obtained results are in favour of the conclusion that with the decrease of pre-slaughter body mass higher values of dressing percentage are realized (BOLAZALI AND KUCUK, 2008). Lower values for dressing percentage of warm carcass (49.71, 49.27 and $48.78 \%$ ) and hot carcass weights $(6.78,7.61$ and $7.02 \mathrm{~kg})$ in kids Hair Goat, Saanen $\times$ Hair Goat $\left(\mathrm{F}_{1}\right.$ and $\mathrm{B}_{1}$ ) slaughtered at the age of 4 months, are reported by YILMAZ ET AL. (2009) and ARGUELLO ET AL. (2007) for dressing percentages in kids of different genotypes. Obtained results for mass of warm and cold carcass with and without head and offal, as well as value of dressing percentage of warm carcass of Balkan goat, are also similar to those established by BECERRIL - HererRA ET AL.. (2006), in kids of Mexican Creole goat breed (59.27\%). The authors state statistically significant correlation of 0.83 and 0.76 for certain slaughter traits such as mass of warm and cold carcass in relation to pre-slaughter body mass, which was slightly lower compared to results obtained in this research (0.97 and 0.95). MARICHAL ET AL. (2003), report similar values of dressing percentage in kids reared on Canary Islands. Considering the expression of slaughter traits in kids of Balkan breed, obtained results should be used for formulating of future programs designed to improve the production of meat from autochthonous goat breeds.

\section{REFERENCES}

Argüello, A., Castro, A., CApote, J., Solomon, N.B. (2007): The influence of artificial rearing and live weight at slaughter on kid carcass characteristics. Journal of Animal and Veterinary Advances 6(1): 20-25. 
Becerril-Hererra, M., GuZman-Pina, O., Alonso-Spilsbury, M., Dorsez-SAn Vicente, E.V., Lemus-Flores, C., Flore-Peinado, S., RAmireZ-Neochoechea, R., MOTA-ROJAS, D. (2006): Morphometry, carcass yield and traits of Mexican Creole goat kids slaughtered and packed in a federal inspection plant. J. Biol. Sci. 6: 604-609.

BOLACALI, M., KUCUK, M. (2008): Fattening performance, Slaughter and carcass characteristics of male kids of coloured Mohair goats and Angora goats x Coloured Mohair goats cross-breed F1. J. Anim. Vet. Adv. 7: 502-507.

Marichal, A., Castro, N., Capote, J., Zamorano, M.J., Arguello, A. (2003): Effects of live weight at slaughter $(6,10$ and $25 \mathrm{~kg})$ on kid carcass and meat quality. Livest. Prod. Sci. 83: 247-256.

MEMIŠI, N. (2000): Quantitative analisis of body development and production traits of Domestic Balkan goats. Ph. D thesis, Faculty of Agriculture, Belgrade, $161 \mathrm{pp}$.

MEMIŠI, N., BAUMANN, F. (2007): Goat Nutrition. Admiralbooks. Belgrade, 230.

MEMIŠI, N., BOŽOVIĆ, V., BAUMANN, F., LATINOVIĆ, D. (1998): Variability of production traits of domestic Balcan goats from the mountain region of Sharplanina. Contemporary agriculture. Vol. 46, No. 3-4, 75-80.

Memiši, N., BAumanN, F. (2002): Goat. Agriculture library. Beograd, SAS Institute (2007): SAS software Version 9.1.3, SAS Institute Inc., Cary, NC, USA. YilmaZ, A., EkIZ, B., OzCAN, B., KAPTAN, C., HANOGLU, H., YildirIR, M. (2009): Effects of crossbreeding indigenous Hair Goat with Saanen on carcass measurements and meat quality of kids under an intensive production system. Animal Science Journal 80: 460-467. 